\title{
SERUM LEVELS OF COPPER AND IRON IN DENGUE FEVER
}

\author{
Rajendiran SOUNDRAVALLY(1), Jacob SHERIN(1), Balakrishna Pillai AGIESHKUMAR(2), Mariya Samadanam DAISY(1), Cherupanakkal CLEETUS(1), \\ Parameswaran NARAYANAN(3), Tamilarasu KADHIRAVAN(4), Sistla SUJATHA(5) \& Kottyen Thazhath HARICHANDRAKUMAR(6)
}

\begin{abstract}
SUMMARY
The role of trace elements in dengue virulence is not yet known. The present study assessed the serum levels of two micronutrients, copper and iron, in cases of dengue fever. The study involved 96 patients of whom 48 had either severe or non-severe forms of dengue (with and without warning signs), and the remaining 48 were patients with other febrile illnesses (OFI), used as controls. Serum levels of copper and iron were evaluated at admission and by the time of defervescence using commercially available kits. At admission, no difference in the level of serum copper was observed between cases and controls. In the group of dengue cases, the copper level was found to be significantly decreased in severe and non-severe cases with warning signs, compared to non-severe cases without warning signs. In contrast, by the time of defervescence the copper level was found to be increased in all dengue cases compared to OFI controls, but no difference was observed among dengue cases. Unlike OFI controls, dengue cases showed an increasing pattern of copper levels from admission until defervescence. On the other hand, no such significant differences were observed in the serum level of iron in the clinical groups, except for a decreased iron level found in severe cases, compared to non-severe dengue without warning signs. The results show that copper is associated with dengue severity and this finding emphasizes the need to investigate the involvement of trace elements in disease severity so as to improve the prognosis of dengue.
\end{abstract}

KEYWORDS: Copper; Iron; Trace elements; Dengue severity; Dengue fever.

\section{INTRODUCTION}

Dengue is considered one of the most important arthropod-borne viral infections and is becoming an emerging public health problem due to its geographical aspects and in its intensity ${ }^{2,4}$. According to the World Health Organization, it is estimated that around 2.5 billion people are at risk of infection, living mainly in tropical and subtropical areas ${ }^{27}$. Infection by dengue virus causes a wide spectrum of disease presentation from non-severe to severe dengue ${ }^{19}$. Several theories have been proposed to explain the pathogenesis of dengue fever and its severe forms, but the precise mechanism is not well understood.

Trace elements are essential for the host defense against infections. They act as activators in controlling biological functions ${ }^{8}$. Changes in the level of micronutrients and its effects have been described in inflammatory responses, cancer cases, parasitic and viral ${ }^{10,11,12,16,25}$ infections. In the case of viral disease, trace elements play an important role by exhibiting immune modulatory functions. Any alterations in the status of trace elements can influence the disease severity ${ }^{1}$. Serum trace elements levels and their ratios are reported to be good markers for diagnosing various diseases, for instance serum trace elements like copper, iron and zinc are considered effective for the diagnosis of viral hepatic diseases ${ }^{15}$. The correlation between trace elements and dengue severity remains an understudied area. Recently, the relationship between serum zinc levels and clinical severity of dengue infection in children was studied by YULIANA et al. ${ }^{29}$. In order to explore the role of trace elements in dengue fever and disease severity, the present study was designed to evaluate the serum levels of copper and iron in dengue fever cases and to correlate them with severe forms of disease.

\section{MATERIALS AND METHODS}

Patient recruitment and sample collection: This research was designed as a nested case-control study conducted at the Jawaharlal Institute for Post Graduate Medical Education and Research (JIPMER), in southern India, and the study protocol has been approved by the institute research and ethics committee. The samples were collected during the dengue fever outbreak in 2012-2013 from the regions of Puducherry and Tamilnadu, India. All the four viral strains have been reported to be circulating in these regions ${ }^{3,17,26}$. A total of 96 patients were enrolled for the study ranging from three to 67 years of age. The subjects recruited for the study were categorized into two groups. Group A included 48 dengue infected cases (39 adults and nine children, with ages varying from three to 50 years) whose infection was confirmed by the positivity of NS1 antigen by means of the Dengue Early ELISA Kit (Pan Bio, Inverness Medical Innovations, Australia), or anti-dengue IgM antibodies

(1) Department of Biochemistry. Jawaharlal Institute of Postgraduate Medical Education and Research, Pondicherry, South India.

(2) School of Chemical and Biotechnology, SASTRA University, Thanjavur, TamilNadu, India.

(3) Department of Pediatrics. Jawaharlal Institute of Postgraduate Medical Education and Research, Pondicherry, South India.

(4) Department of Medicine. Jawaharlal Institute of Postgraduate Medical Education and Research, Pondicherry, South India.

(5) Department of Microbiology. Jawaharlal Institute of Postgraduate Medical Education and Research, Pondicherry, South India.

(6) Department of Statistics, Jawaharlal Institute of Postgraduate Medical Education and Research, Pondicherry, South India.

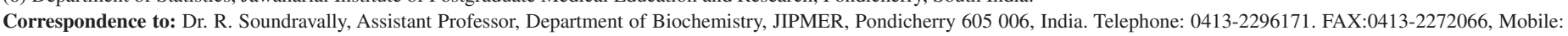

91-9442214256. E-mail: soundy27@yahoo.co.in 
SOUNDRAVALLY, R.; SHERIN, J.; AGIESHKUMAR, B.P.; DAISY, M.S.; CLEETUS, C.; NARAYANAN, P.; KADHIRAVAN, T.; SUJATHA, S. \& HARICHANDRAKUMAR, K.T. - Serum levels of copper and iron in dengue fever. Rev. Inst. Med. Trop. Sao Paulo, 57(4): 315-20, 2015.

using Capture ELISA Kit, (National Institute of Virology, Pune), or antidengue IgG antibodies using SCIMEDX Microwell ELISA IgG, USA, or viremia by Conventional Reverse Transcriptase RT PCR method ${ }^{14}$. The World Health Organization (WHO-2009) grading system was used to classify patients infected with dengue virus ${ }^{27}$. Dengue fever was divided into dengue without warning signs, dengue with warning signs and severe dengue. Patients with fever, fulfilling any of these criteria: nausea, vomiting, rash, aches and pains, leukopenia, and positive tourniquet test, were considered "dengue without warning signs". In addition, if the patient presents any of these clinical conditions: abdominal pain, persistent vomiting, clinical fluid accumulation, mucosal bleeding, lethargy, restlessness, liver enlargement $>2 \mathrm{~cm}$, increase in hematocrit concurrent with rapid decrease in platelet count, it was considered "dengue with warning signs". Severe dengue was defined as dengue with at least one of the following criteria: severe plasma leakage leading to shock or fluid accumulation with respiratory distress, severe bleeding evaluated by the attendant physician and severe organ involvement such as elevated liver enzymes ( $\geq 1000 \mathrm{IU} / \mathrm{L}$ ), CNS (impaired consciousness), heart failure as well as other organs failure. Group $B$ included 48 age and sex-matched patients with other febrile illness (OFI). OFIs would be defined as those patients with short febrile illness $(<2$ weeks) who are negative for dengue NS1 antigen, anti-IgM/IgG dengue antibodies, virus by Reverse Transcriptase PCR and no obvious bacterial, rickettsial or protozoan etiology. Known cases of chronic inflammatory disease, iron deficiency anemia, and Wilson's disease were excluded from the study. The clinical and demographic profiles as well as laboratory characteristics of the study subjects were recorded. After taking written informed consent, $3 \mathrm{~mL}$ of blood were collected in each of the study time points, one sample within 24 hours of admission, and another sample during the follow up coinciding with the time of defervescence, and at the same time points for OFI patients. The serum was separated to analyze copper and iron levels.

Assay of copper and iron: Serum levels of copper and iron were measured using commercially available kits supplied by CORAL DIAGNOSTICS Ltd, INDIA, in a semi-automatic analyzer (OLYMPUS - AU 400, USA). In brief, the estimation of copper was based on the principle that copper, released from ceruloplasmin, in an acidic medium reacts with Di- Br- PAESA to form a colored complex which is measured at $548 \mathrm{~nm}$. Iron was estimated by the Ferrozine method in which iron, bound to transferrin, is released in an acidic medium and the ferric ions are reduced to ferrous ions. The Fe (II) ions react with ferrozine to form a violet-coloured complex. Intensity of the complex formed is directly proportional to the amount of iron present in the sample which was quantified at $570 \mathrm{~nm}$. The normal levels of serum copper in male, female and children are 80-140, 80-155, and 30-150 micro gram/dL respectively, and serum iron in male, female and children are: 60-160, 35-145, 150-220 micro gram/dL, respectively.

Statistical analysis: The sample size calculation was based on a previous study, which evaluated the serum iron levels in patients with viral hepatic disease and healthy controls ${ }^{15}$. We calculated the sample size using the Open Source Epidemiology Statistics for Public Health, version 3.01. Considering the subgroup analysis and $25 \%$ of dropouts, 48 cases and the same number of controls were recruited. The calculation was based on the assumption of an alpha error of 0.05 with $90 \%$ power and $95 \%$ confidence interval. Results were expressed as mean \pm standard deviation and $p$ value $<0.05$ was considered as statistically significant.
The Chi square test was used to compare the groups and the Mann Whitney-U test to compare characteristics of the studied groups, as well as the platelet count. Differences in copper and iron levels between dengue fever patients and OFI ones were evaluated using one way ANOVA. The paired student ' $t$ ' test was used to assess differences between the base line sample (admission) and the follow up sample (defervescence). All calculations were performed using the SPSS version 19.0.

\section{RESULTS}

Out of 96 study subjects, the average age of dengue fever patients and OFI patients was comparable: $25.06 \pm 14.27$ and $25.75 \pm 13.09$, respectively (Table 1), $p=0.81$. All dengue fever cases were classified based on the WHO 2009 criteria so that 13 patients were categorized as presenting dengue without warning signs, 15 as dengue with warning signs, and 20 as severe dengue. The average day of defervescence was found to be 4.2 for dengue cases and 4.0 for the OFI controls, respectively $(p=0.18)$. Table 1 shows the clinical profile, hematological characteristics and seropositivity of dengue patients. Clinical signs/symptoms such as petechiae, third space collection, abdominal pain, vomiting, headache and thrombocytopenia were significantly more frequent among dengue cases compared to OFI. Petechiae, third space collection and thrombocytopenia were more frequent in patients with severe dengue compared to other dengue groups as shown in Table 1.

No significant differences in copper and iron levels between subjects with OFI and all dengue cases were seen at admission (Table 2), whereas a significant decrease in the levels of copper was observed among severe dengue and dengue with warning signs cases compared to dengue cases without warning signs. In a similar way, a reduction in the serum iron levels in severe dengue compared to dengue cases without warning signs was recorded (Table 2). Around the time of defervescence only the copper level was found to be significantly increased in patients with dengue fever in comparison to OFI patients (Table 3). Among the dengue cases, severe dengue reached a higher level of serum copper than the other groups, however no statistical significant differences were observed (Table 3). Copper levels showed an increasing pattern from admission up to defervescence in all dengue cases, and also among all dengue groups, whereas in OFI controls a significant decrease was observed (Fig. 1). Serum iron levels, on the other hand, did not show any significant difference between dengue cases and controls with respect to the levels obtained on the date of admission (DOA) and date of defervescence (DOD) (Fig. 2).

\section{DISCUSSION}

Trace elements play an important role in disease progression and the state of fluctuation in their serum levels have been documented during most viral infections. Influence of trace elements have been studied in a large number of viral infections such as HIV, Hepatitis B, $\operatorname{etc}^{7,11,18}$ however, the knowledge of micronutrient involvement during dengue fever remains unclear. A number of trace elements, especially those having oxidative properties such as copper, iron, and zinc, play an important role in viral disease progression. Among these important trace elements, the present study estimated the levels of copper and iron, whereas serum zinc levels have been recently studied and associated with dengue severity ${ }^{28,29}$. In the present study, on the day of admission, copper levels were found to be significantly decreased in dengue patients with warning signs and severe dengue compared to 


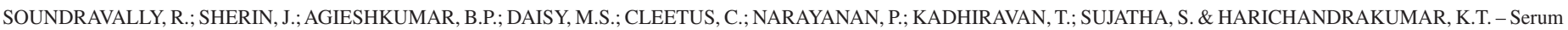
levels of copper and iron in dengue fever. Rev. Inst. Med. Trop. Sao Paulo, 57(4): 315-20, 2015.

Table 1

Clinical, hematological profile and seropositivity of the patients in the study groups

\begin{tabular}{|c|c|c|c|c|c|c|}
\hline & Characteristics & $\begin{array}{l}\text { Other febrile } \\
\text { illness } \\
(n=48) \\
\mathbf{N}(\%)\end{array}$ & $\begin{array}{l}\text { All dengue cases } \\
\qquad \begin{array}{c}(\mathbf{n}=48) \\
\mathbf{N}(\%)\end{array}\end{array}$ & $\begin{array}{l}\text { Dengue without } \\
\text { warning sign } \\
(\mathbf{n}=13) \\
\mathbf{N}(\%)\end{array}$ & $\begin{array}{c}\begin{array}{c}\text { Dengue with } \\
\text { warning sign } \\
(\mathbf{n}=15) \\
\mathbf{N}(\%)\end{array}\end{array}$ & $\begin{array}{l}\text { Severe dengue } \\
\qquad \begin{array}{c}(\mathbf{n}=\mathbf{2 0}) \\
\mathbf{N}(\%)\end{array}\end{array}$ \\
\hline Age & & $25.75 \pm 13.09$ & $25.06 \pm 14.27$ & $25.07 \pm 13.67$ & $24.33 \pm 16.60$ & $25.60 \pm 13.48$ \\
\hline \multirow{2}{*}{ Gender } & Male & $21(43.8)$ & $22(45.8)$ & $7(53.8)$ & $4(26.7)$ & $11(55)$ \\
\hline & Female & $27(56.2)$ & $26(54.2)$ & $6(46.2)$ & $11(73.3)$ & $9(45)$ \\
\hline \multirow{5}{*}{$\begin{array}{l}\text { Clinical } \\
\text { characteristics }\end{array}$} & Petechiae & $2(4.2)$ & $19(39.6)^{\text {aa }}$ & $2(15.4)$ & $2(13.3)$ & $15(75)^{* * \# \#}$ \\
\hline & $\begin{array}{c}\text { Third space } \\
\text { collection (pleural/ } \\
\text { peritoneal) }\end{array}$ & $3(6.2)$ & $10(20.8)^{\mathrm{a}}$ & 0 & 0 & $10(50)^{* \#}$ \\
\hline & Abdominal pain & $8(16.7)$ & $21(43.7)^{\mathrm{a}}$ & 0 & $15(100)$ & $6(30)^{* \# \#}$ \\
\hline & Vomiting & $7(14.5)$ & $32(66.7)^{\text {aa }}$ & $8(61.5)$ & $11(73.3)$ & $13(65)$ \\
\hline & Headache & $13(27.1)$ & $30(62.5)^{\text {aa }}$ & $11(84.6)$ & $12(80)$ & $7(35)^{* \#}$ \\
\hline $\begin{array}{l}\text { Hematological } \\
\text { parameters }\end{array}$ & $\begin{array}{l}\text { Platelet count } \\
\left(\text { cells } / \mathrm{mm}^{3}\right)\end{array}$ & $155290 \pm 103737$ & $53167 \pm 26193$ & $61231 \pm 24028$ & $65867 \pm 21353$ & $38400 \pm 24396$ *\# \\
\hline \multirow{4}{*}{$\begin{array}{l}\text { Positivity for } \\
\text { dengue }\end{array}$} & NS1 Ag & 0 & $25(52.1)$ & $8(61.5)$ & $4(26.7)$ & $13(65)$ \\
\hline & $\begin{array}{l}\text { Anti dengue } \mathrm{IgG} \\
\text { antibody }\end{array}$ & 0 & $24(50)$ & $5(38.5)$ & $7(46.7)$ & $12(60)$ \\
\hline & RT PCR (Viremia) & 0 & $29(60.4)$ & $9(69.2)$ & $9(60)$ & $11(55)$ \\
\hline & $\begin{array}{l}\text { Anti dengue } \operatorname{IgM} \\
\text { antibody }\end{array}$ & 0 & $40(83.3)$ & $9(69.2)$ & $14(93.3)$ & $17(85)$ \\
\hline
\end{tabular}

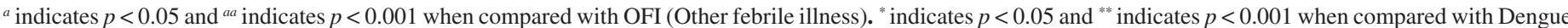

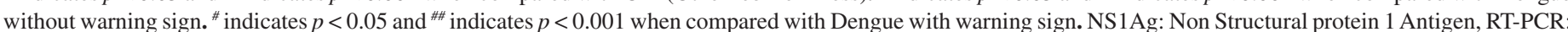

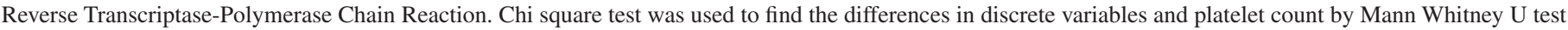

Table 2

Serum levels of copper and iron in study groups at the date of admission

\begin{tabular}{|c|c|c|c|c|c|}
\hline Parameters & Other febrile illness & All dengue cases & $\begin{array}{l}\text { Dengue without } \\
\text { warning sign }\end{array}$ & $\begin{array}{l}\text { Dengue with } \\
\text { warning sign }\end{array}$ & Severe dengue \\
\hline Copper (micro gram/dL) & $121.98 \pm 40.04$ & $107.92 \pm 35.11$ & $139.48 \pm 29.40$ & $99.71 \pm 22.82^{\mathrm{a}}$ & $99.03 \pm 37.82^{\mathrm{a}}$ \\
\hline Iron (micro gram/dL) & $41.07 \pm 44.63$ & $52.79 \pm 40.11$ & $87.65 \pm 27.83$ & $48.40 \pm 42.68$ & $39.73 \pm 35.72^{\mathrm{a}}$ \\
\hline
\end{tabular}

andicates $p<0.05$ when compared with dengue without warning sign using one way ANOVA.

Table 3

Serum levels of copper and iron in OFI and clinical groups of dengue at the day of defervescence

\begin{tabular}{|c|c|c|c|c|c|}
\hline Parameters & Other febrile illness & All dengue cases & $\begin{array}{c}\text { Dengue without } \\
\text { warning sign }\end{array}$ & $\begin{array}{l}\text { Dengue with } \\
\text { warning sign }\end{array}$ & Severe dengue \\
\hline Copper (micro gram/dL) & $96.35 \pm 37.73$ & $162.14 \pm 35.64^{\mathrm{aa}}$ & $162.60 \pm 4.94$ & $150.60 \pm 24.22$ & $168.28 \pm 42.52$ \\
\hline Iron (micro gram/dL) & $36.79 \pm 31.02$ & $46.98 \pm 34.97$ & $47.80 \pm 10.74$ & $46.61 \pm 17.60$ & $47.05 \pm 44.45$ \\
\hline
\end{tabular}

aaindicates $p<0.001$ when compared with other febrile illness using one way ANOVA. 
SOUNDRAVALLY, R.; SHERIN, J.; AGIESHKUMAR, B.P.; DAISY, M.S.; CLEETUS, C.; NARAYANAN, P.; KADHIRAVAN, T.; SUJATHA, S. \& HARICHANDRAKUMAR, K.T. - Serum levels of copper and iron in dengue fever. Rev. Inst. Med. Trop. Sao Paulo, 57(4): 315-20, 2015.

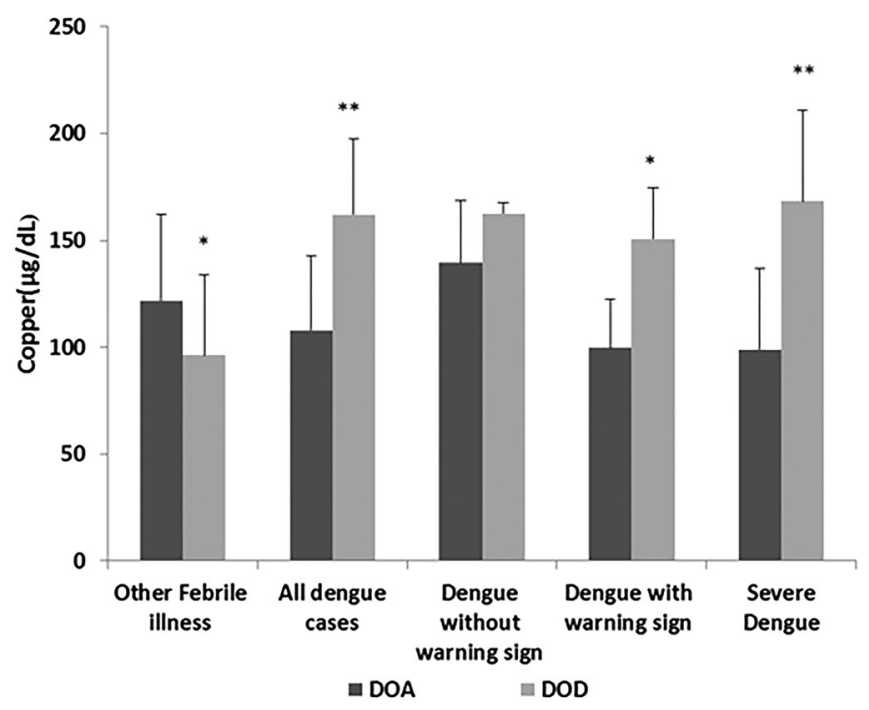

Fig. 1 - Comparison of serum levels of copper in other febrile illness, all dengue cases, dengue without warning signs, dengue with warning signs and severe dengue between the date of admission and the date of defervescence. DOA: Day of admission; DOD: Day of defervescence. * indicates $p<0.05$ in comparison to DOA. ** indicates $p<0.001$ in comparison to DOA. $p$-value was calculated by paired Student ' $\mathrm{t}$ ' test.

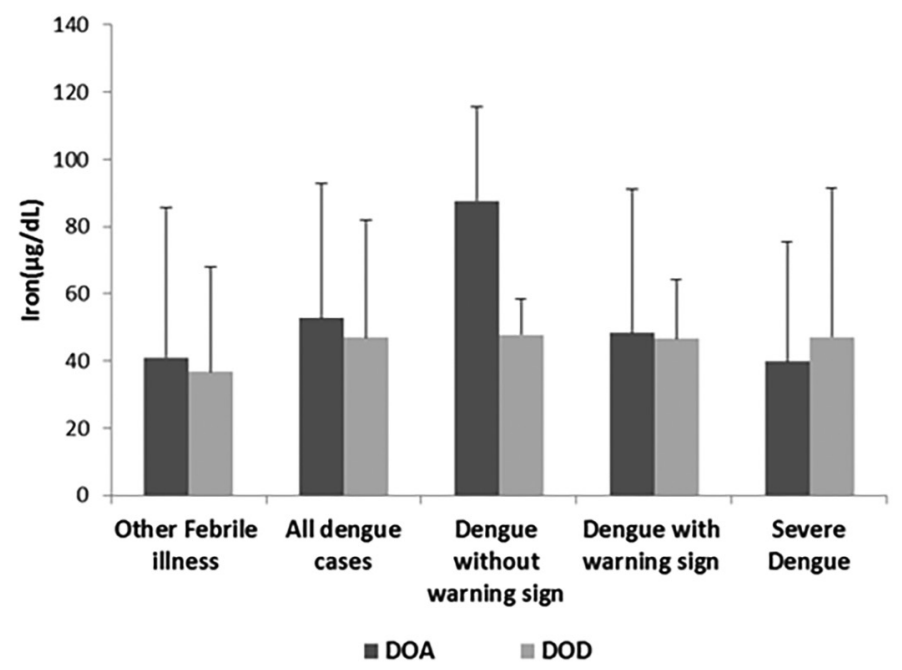

Fig. 2 - Comparison of serum levels of iron in other febrile illness, all dengue cases, dengue without warning signs, dengue with warning signs and severe dengue between the date of admission and the date of defervescence. DOA: Date of admission; DOD: Date of defervescence. Statistical analysis was carried out using paired Student ' $t$ ' test.

dengue cases without warning signs and in the same period iron levels were also significantly decreased in severe dengue cases compared to cases of dengue without warning signs. However, around the time of defervescence copper levels have increased in all dengue cases compared to OFI, even though these levels have failed to distinguish between dengue cases. In comparison with DOA and DOD, a decreasing pattern of copper levels was observed in controls while an increasing pattern was seen in dengue cases. The results are in accordance with earlier findings that documented increased content of copper in viral hepatitis infections ${ }^{13,15}$ and they were later related to a worsening of viral hepatitis. Similarly, a significantly increased level of copper was also reported in retrovirus infected mice ${ }^{21}$. Alterations in the levels of micronutrients influence the oxidative stress during viral infections. Copper acts as a cofactor of antioxidant enzymes to protect the body from the oxidative stress response under normal circumstances. During severe viral infections the anti-oxidative capacity will be outdated and toxic lipid peroxidation products will accumulate in the cells ${ }^{6}$. Although normally bound to proteins, copper may be released and become free to catalyze the formation of free radicals that have the capacity to initiate an oxidative damage and interfere with cellular events ${ }^{9}$. Thus a stable level of serum copper should be maintained in order to protect the cell from free radical toxins. In the case of dengue, we have previously reported the participation of oxidative stress response in dengue severity ${ }^{23,24}$. We have also evidenced the increment of an oxidative stress-responsive molecule called malondialdehyde in dengue severe cases and observed an association between proinflammatory cytokines and oxidative stress response in severe dengue ${ }^{22}$. Since excessive copper levels are highly toxic and results in cellular damage, the increased levels of copper in severe dengue compared to non-severe cases in the present study may trigger the oxidative stress response by releasing free radicals in severe cases. Intriguingly, the increasing pattern of copper levels was observed only in dengue cases whereas in OFI ones, copper levels were found to decline (Fig. 1). Apart from the oxidative stress response, changes in the copper levels were also reported to influence the release of proinflammatory cytokines ${ }^{8}$. However, further investigation is needed to understand whether copper levels play any role in the release of proinflammatory cytokine in severe cases of dengue.

In the present study we have observed a decrease of iron levels in severe dengue on the day of admission. But no significant difference was observed at the time of defervescence. The earlier studies on iron reported heterogeneous results, for instance, significantly lower levels of iron were reported in hepatocellular carcinoma patients compared to healthy controls ${ }^{15}$, whereas the same study did not find changes in the levels of serum iron in liver cirrhosis patients compared to healthy controls. Thus there exists a variation in the iron level based on the type of infection and study conditions. Since the serum iron level has an impact on liver damage, studies have been conducted in dengue patients ${ }^{20}$ to investigate whether changes in iron levels could indicate disease severity, though the present study did not observe any significant differences in the level of serum iron between dengue patients and OFI ones. In OFI cases, patients were treated with doxycycline and omipressol. Doxcycline is a known chelator for divalent cations and some studies have suggested that iron interacts with drugs such as tetracycline leading to a decrement of the drug bioavailability ${ }^{5}$. However it has not been well-documented that these drugs would alter the circulating levels of copper and iron in normal conditions. Even so, in the present study, dengue cases received only supportive treatment and none of them received antibiotics. However, an important and still unresolved issue is whether the alterations in the levels of serum iron occur because of the acute viral infection or a pre-existing rise in iron predisposes patients to more severe form of the disease. Some of the limitations of the present study include: a separate analysis of pediatric and adult cohort was not done because of the limited sample size. The study did not characterize the dengue serotypes and the primary/secondary infective status of the dengue cases. So far no study has explored the association between dengue serotypes and trace elements in dengue fever. 
We conclude that copper levels were found to be high in dengue fever patients by the time defervescence and these levels are associated with disease severity. These results emphasize the need to investigate the involvement of micronutrients in dengue fever to understand the role of preexisting micronutrient status in the development of severe forms of dengue.

\section{RESUMO}

\section{Níveis séricos de cobre e ferro na dengue}

O papel dos elementos-traço na virulência da dengue não é ainda conhecido. O presente estudo avaliou os níveis séricos de dois micronutrientes, cobre e ferro, em casos de dengue. O estudo envolveu 96 pacientes dos quais 48 apresentavam dengue grave ou não grave (com ou sem sinais de alerta), e outros 48 pacientes com outras doenças febris (OFI) representaram os controles. Níveis séricos de cobre e ferro foram avaliados na admissão e no momento da defervescência usando kits comerciais disponíveis. À admissão, nenhuma diferença nos níveis séricos de cobre foi observada entre casos e controles. No grupo com dengue, os níveis de cobre se encontravam significativamente reduzidos nos casos graves e não graves com sinais de alerta, em comparação aos casos não graves sem sinais de alerta. Contrariamente, no momento da defervescência os níveis de cobre se encontravam aumentados em todos os casos de dengue em relação aos controles com outras doenças febris (OFI), no entanto, nenhuma diferença foi observada entre os casos de dengue. Diferentemente dos pacientes com outras doenças febris, os casos de dengue mostraram um padrão de elevação dos níveis de cobre do dia da admissão até a defervescência. Por outro lado, estas diferenças não foram observadas em relação aos níveis de ferro entre os dois grupos, com exceção de níveis de ferro reduzidos encontrados nos casos graves, em comparação aos não graves com sinais de alerta. Os resultados mostram que o cobre está associado à gravidade da dengue e esta observação enfatiza a necessidade de investigação do envolvimento de elementostraço na gravidade da doença para melhorar o prognóstico da dengue.

\section{CONFLICT OF INTEREST}

None declared.

\section{REFERENCES}

1. Beck MA. Antioxidants and viral infections: host immune response and viral pathogenicity. J Am Coll Nutr. 2001;20:384S-8S.

2. Bhatt S, Gething PW, Brady OJ, Messina JP, Farlow AW, Moyes CL, et al. The global distribution and burden of dengue. Nature. 2013;496:504-7.

3. Bhuvaneswari CK, Raja RS, Arunagiri K, Mohana S, Sathiyamurthy K, Krishnasamy $\mathrm{K}$, et al. Dengue epidemiology in Thanjavur and Trichy district, Tamilnadu - Jan 2011-Dec 2011. Indian J Med Sci. 2011;65:260-7.

4. Brady OJ, Gething PW, Bhatt S, Messina JP, Brownstein JS, Hoen AG, et al. Refining the global spatial limits of dengue virus transmission by evidence-based consensus. PLOS Negl Trop Dis. 2012;6:e1760.

5. Campbell NR, Hasinoff BB. Iron supplements: a common cause of drug interactions. $\mathrm{Br}$ J Clin Pharmacol. 1991;31:251-5
6. Cemek M, Dede S, Bayiroglu F, Caksen H, Cemek F, Mert N. Relationship between antioxidant capacity and oxidative stress in children with acute hepatitis A. World J Gastroenterol. 2006;12:6212-5.

7. Cesur S, Cebeci SA, Kavas GO, Aksaray S, Tezeren D. Serum copper and zinc concentrations in patients with chronic hepatitis B. J Infect. 2005;51:38-40.

8. Chaturvedi UC, Shrivastava R, Upreti RK. Viral infections and trace elements : a complex interaction. Curr Sci. 2004;87:1536-54.

9. Florianczyk B. Copper and metallothioneins in cancer cells. Ann Univ Mariae Curie Skłodowska Med. 2003;58:390-3.

10. Friis H, Kaestel P, Nielsen N, Simonsen PE. Serum ferritin, alpha-tocopherol, betacarotene and retinol levels in lymphatic filariasis. Trans R Soc Trop Med Hyg. 2002;96:151-6

11. Friis H, Michaelsen KF. Micronutrients and HIV infection: a review. Eur J Clin Nutr. 1998;52:157-63.

12. Haraguchi Y, Sakurai H, Hussain S, Anner BM, Hoshino H. Inhibition of HIV-1 infection by zinc group metal compounds. Antiviral Res. 1999;43:123-33.

13. Hatano R, Ebara M, Fukuda H, Yoshikawa M, Sugiura N, Kondo F, et al. Accumulation of copper in the liver and hepatic injury in chronic hepatitis C. J Gastroenterol Hepatol. 2000;15:786-91.

14. Kong YY, Thay CH, Tin TC, Devi S. Rapid detection, serotyping and quantitation of dengue viruses by TaqMan real-time one-step RT-PCR. J Virol Methods. 2006;138:123-30.

15. Lin CC, Huang JF, Tsai LY, Huang YL. Selenium, iron, copper, and zinc levels and copper-to-zinc ratios in serum of patients at different stages of viral hepatic diseases. Biol Trace Elem Res. 2006;109:15-24

16. McMillan DC, Talwar D, Sattar N, Underwood M, O'Reilly DS, McArdle C. The relationship between reduced vitamin antioxidant concentrations and the systemic inflammatory response in patients with common solid tumours. Clin Nutr. 2002;21:161-4.

17. Paramasivan R, Dhananjeyan KJ, Leo SV, Muniaraj M, Thenmozhi V, Rajendran R, et al. Dengue fever caused by dengue virus serotype-3 (subtype-III) in a rural area of Madurai district, Tamil Nadu. Indian J Med Res. 2010;132:339-42.

18. Rashed MN. The role of trace elements on hepatitis virus infections: a review. J Trace Elem Med Biol. 2011;25:181-7.

19. Rigau-Pérez JG, Clark GG, Gubler DJ, Reiter P, Sanders EJ, Vorndam AV. Dengue and dengue haemorrhagic fever. Lancet. 1998;352:971-7.

20. Seneviratne SL, Malavige GN, de Silva HJ. Pathogenesis of liver involvement during dengue viral infections. Trans R Soc Trop Med Hyg. 2006;100:608-14.

21. Shahbazian LM, Wood S, Watson RR. Ethanol consumption and early murine retrovirus infection influence liver, heart, and muscle levels of iron, zinc, and copper in C57BL/6 mice. Alcohol Clin Exp Res. 1994;18:964-8.

22. Soundravally R, Hoti SL, Patil SA, Cleetus CC, Zachariah B, Kadhiravan T, et al. Association between proinflammatory cytokines and lipid peroxidation in patients with severe dengue disease around defervescence. Int J Infect Dis. 2014;18:68-72.

23. Soundravally R, Sankar P, Bobby Z, Hoti SL. Oxidative stress in severe dengue viral infection: association of thrombocytopenia with lipid peroxidation. Platelets. 2008; $19: 447-54$

24. Soundravally R, Sankar P, Hoti SL, Selvaraj N, Bobby Z, Sridhar MG. Oxidative stress induced changes in plasma protein can be a predictor of imminent severe dengue infection. Acta Trop. 2008;106:156-61. 
SOUNDRAVALLY, R.; SHERIN, J.; AGIESHKUMAR, B.P.; DAISY, M.S.; CLEETUS, C.; NARAYANAN, P.; KADHIRAVAN, T.; SUJATHA, S. \& HARICHANDRAKUMAR, K.T. - Serum levels of copper and iron in dengue fever. Rev. Inst. Med. Trop. Sao Paulo, 57(4): 315-20, 2015.

25. Tomkins A. Assessing micronutrient status in the presence of inflammation. J Nutr. 2003;133:1649S-55S

26. Victor TJ, Malathi M, Gurusamy D, Desai A, Ravi V, Narayanasamy G, et al. Dengue fever outbreaks in two villages of Dharmapuri district in Tamil Nadu. Indian J Med Res. 2002;116:133-9.

27. Widagdo. Blood zinc levels and clinical severity of dengue hemorrhagic fever in children. Southeast Asian J Trop Med Public Health. 2008;39:610-6.
28. World Health Organization. Dengue guidelines for diagnosis, treatment, prevention and control. Geneva: WHO; 2009. Available from: http://www.who.int/tdr/publications/ documents/dengue-diagnosis.pdf

29. Yuliana N, Fadil RM, Chairulfatah A. Serum zinc levels and clinical severity of dengue infection in children. Paediatr Indones. 2009;49:309-14.

Received: 16 December 2013

Accepted: 3 November 2014 